\title{
Defining Pop-up Stores
}

Ghalia Boustani

UFR 06, Paris 1 Panthéon Sorbonne, Paris, France

\section{Keywords}

pop-up stores; pop-up retailing; ephemeral retailing

\begin{abstract}
Purpose of the research: The purpose of this paper is to define pop-up stores.

Design/Methodology: Adopting an exploratory research design, semi-structured interviews and field observations were undertaken with brand managers of different types of pop-up stores and at different industry levels in Lebanon.

Results/findings: A pop-up store is guided by a clear strategy to meet specific objectives using available resources. Research findings highlight a clear distinction between pop-up stores developed by newly established brands and mature brands in terms of purpose and function. The two brand classes can each manifest in four types of pop-up stores: pop-up as a distribution channel, pop-up as a communications channel, pop-up as a distribution and communications channel and pop-up complementing a distribution channel.

Practical implications and conclusions: This study qualitatively explores brand managers' understanding of pop-up stores, their perceptions and their uses in the Middle Eastern market; a market that hasn't yet been explored in academic research related to these types of stores. It presents, defines and contextualizes a pop-up store and anchors it among new types of retail formats.
\end{abstract}

Corresponding author: Ghalia Boustani

Email addresses for the corresponding author: ghaliaboustani@gmail.com

The first submission received: $9^{\text {th }}$ September 2021

Revised submission received: $4^{\text {th }}$ October 2021

Accepted: 20 $0^{\text {th }}$ October 2021

\section{Introduction}

\section{The business of pop-up}

The development of environmental and social factors coupled with the customer's everchanging consumption preferences and how they wish to consume greatly affect retail formats; they mutate previous or older formats and morph them into context-relevant ones; pop-up stores are the latest examples. This paper aims to define pop-up stores and to explore available types that can be adopted by different brands.

Pop-up retailing has captured the attention of brands through the past decade, and they have become "more than just trends"; their implantation throughout the years has given them a considerable weight and an interesting dimension. To illustrate their success, the pop-up industry has reached a 10-billiondollar figure, according to the "Pop-Up Republic", a brand-property matchmaking agency. Since the organization's set up in 2012, more than 30000 retail brands and restaurants have registered on the company's website to search for adequate spaces to set up their pop-up stores.

Other short-term leasing companies such as Go Vacant (Go Vacant, 1999), Storefront and Appear Here specialize in finding temporary properties for brands who wish to engage temporary retail; this demonstrates the extent to which brands needed to rethink their distribution strategies. Finding a temporary location is now easily performed with the three-step process, as Storefront communicates on its website: "Choose a location, connect, launch your project" (Storefront, n.d.).

A "Business Insider" article (Kim, 2016) revealed that Amazon, an e-commerce giant, is doubling its points of sales with forecasted plans to invest in up to 100 pop-up stores in American commercial spaces. Such an announcement draws attention that major online retailers, like Amazon, are marrying their virtual presence with a physical one, and thus embarking on a new winning relationship. Most pure 
players that engaged in pop-up stores have noticed an increase in sales during the event's lifetime (Kim, 2016 and Addady, 2016).

These types of stores are not restricted to fashion brands; pop-up hotels, restaurants, and parks are all around us (Mandelbaum, 2013). Initially, the definition of pop-up shops was attributed to small merchants, in towns or countrysides, who set up playful temporary installations, infiltrated into the retail landscape and closed down once their proposed merchandise was sold out. Pop-up stores are conceived in different forms and formats, different sizes and can be found in diverse locations: A concession (store in a shop), a gallery or an event space, a kiosk or stand in a mall or department, a motorized vehicle, a hangar or inflatable balloon or modular structure or a vacant space at the street level; the most popular format so far (Boustani, 2021).

\section{The evolution of pop-up stores}

The origin of the term "pop-up" (Stephens, 2012) is traced back to an event that was observed by American managers who were visiting Japan. The "pop-up" pioneers observed Japanese customers queuing for hours to get hold of a limited-edition item. Once the stock sold out, the store was simply closed before another stock or brand arrived (Gagliordi, 2012 and Hutchison, 2009). This was the key element to shaping the pop-up concept in Los Angeles. The phenomenon gave birth to short-term leasing online platforms where brands could find spaces that meet their requirements for pop-up stores.

A pop-up store seems to equally benefit the customer and the retailer: To the former, it engages a feeling of superiority, excitement and happiness by providing fully sensorial experiences, and giving brands the chance to manifest in different locations. To the latter, the advantage is minimizing risk (Dean, 2012), controlling the cost of set-up, testing or experimentation and stimulating a considerable movement of stock.

The attractiveness of, and the attraction to pop-up stores lies in their limited duration and the imprecision of their life spam (Shopify, n.d.); this is one of their characterizing advantages. "Here today, gone tomorrow" or, "now you see it; now you don't" (Economist, 2009) reflects the urgency that motivates customers to take instant actions due to the probability of not finding the pop-up tomorrow. This keeps taking people by surprise (Koch, 2006), engaging and inciting them (Kerr, 2007) to visit "clandestine stores" (Dean, 2012) before they disappear. Seasonality plays a key determinant (Shopify, n.d.) in the conception and later on pop-up stores' success. It is during times when customers are most vulnerable to take any action, such as exploring, tasting, trying, participating and purchasing, that putting a pop-up store upfront seems most relevant.

While an ephemeral store can be characterized by its "portable" distribution concept (Losif, 2015), it can also serve as a communications tool, delivering the brand's promise to customers (Shopify, n.d.); it is characterized by its strong abilities to reflect a concept and transport it to the audience. A major benefit is that mounting or dismantling pop-up stores (Hallisy, 2006 and Ryan, 2008). This phenomenon opens up a new, unconventional and inexpensive form of retailing (Carapiet, 2009). These stores serve all types of brands, especially digital natives, as they give them the ability to "take a physical form".

Despite the many advantages of pop-up stores, they can have some shortcomings. If relied on as a sole brand distribution channel, a pop-up store can not necessarily support the brand's sustainability, due to its short duration. Moreover, the impact of these stores may disappear if the concept lasts a long time or if the same concept is repeated several times. Besides, there is only a short period to generate profits from a specific ephemeral store and thus making it very difficult for a brand to generate profitable outcomes assuring the brand's survival and sustainability. Finding a location or securing the right lease for the popup is not easy especially when the brand has limited budgets but still aims for popping up at a particular location and a specific period (Tomlinson, 2014).

Crucial to a pop-up store's conception is the choice of location. It can help in giving the store more visibility and facilitate customers' accessibility. A particularly strategic location can attract competition and transform a site into an attractive destination. When it comes to selecting a location, a pop-up store can choose to appear in abandoned sites that it eventually revives and reinvents (Horne, 2014), locations that it creates (Daily Star, 2015) or locations that happen to be in attractive neighbourhoods.

Brands couple up efforts to draw customers into the pop-up store by sharing with them important information on social media platforms (Marciniak \& Budnarowska, 2009). Once at the location or the 
event, customers get in touch with the brand as well as other customers and can revert to social media sites to share or comment about their visit to the pop-up store. It seemed that e-commerce would negatively affect the presence of traditional (physical) stores or push them to redefine their offers. Nevertheless, it seems that the development of new physical formats support, complement or revitalize, online stores (Diegel, 2014) by injecting novelty and reducing dullness (Fortini, 2004).

A pop-up store is considered a communications tool that the brand relies on to trigger positive wordof-mouth (Boustani, 2019). Some consider that it is an alternative marketing communication approach that the brand employs for strategic or tactical reasons and tailors to individuals who are actively seeking new and lively retail experiences (Sherman, 2008).

\section{The difference between pop-up stores and traditional stores}

When comparing a pop-up store to a traditional store, an interesting aspect stands out: a pop-up store resembles an event that amazes and entertains thanks to animations and activities that it offers. The Cambridge dictionary defined the pop-up as a store that opens suddenly and for a short period, taking advantage of empty spaces (Cambridge Dictionary, n.d.) and creating friendly moments of socialization with customers and amongst customers; it is an event to which the customer is invited to and in which he participates and feels privileged. The traditional point of sale, on the other hand, becomes a stable anchor that efficiently manifests, and on a regular rhythm, an exhaustive offering answering to customers' desires (Klépierre \& QualiQuanti, 2015). For brands and retailers that are looking for "casual" marketing strategies, the choice of pop-up stores supports them with introducing new products and expanding their offerings.

The pop-up store is a "quirky" store allowing the brand to keep its independence in terms of physical look and representation; it can move its display and equipment as much as needed, where needed (Newton, 2017) and go to meet customers instead of urging customers to visit (Girish, 2016). It generates a feeling of urgency in the sense of "get it while it lasts" and therefore, drives instant actions from them. With pop-up stores, brands can personify, give form or even validate in "real-time" ideas, concepts or communications that have been shared giving customers an in-depth understanding of the brand's value proposition.

Gilles Lipovetsky's postmodern philosophy explains that: "in the new economy of capitalism, it is about soliciting emotions, stimulating emotions, dreaming, feeling and entertaining" (Lipovetsky \& Serroy, 2016). Today's customers relate pop-up stores to happy and entertaining shopping experiences as they are constantly presenting animations and surprises (Influencia, 2015). They visit pop-up stores to live a unique and different shopping experience (Filser, 2011). As customers are looking for new experiences on one hand and brands are investing in providing customers with experiences, on the other hand, ephemeral is becoming a "structural principle" (Picot- Coupey, 2012).

\section{Research aims}

A clear understanding of the pop-up store, in terms of what it is or where it stands amongst retail channels or other brand channels, has not yet been fully explored in academic literature. There seems to be a blurry delineation of the concept confusing the conceptualization of the term. Moreover, there is no definition for pop-up stores and many concepts could be interchangeably found across literature; however, definitions serve a given description of these store types given a particular time, environment or situation.

Despite pop-up store diffusion and adoption by many brands and retailers, very little academic literature studied the topic. These studies focused on the context of fashion and luxury brands, on pop-up stores as a foreign operations mode or as an international development network. Moreover, studies have tightly connected pop-up stores to experiential marketing and have attempted to explain the phenomenon of exciting customers rather than look at pop-up stores from the brand's organization stand. The literature review detailed each of these concepts by drawing a line from a starting point to an ending point interlinking with pop-up stores. Thus, we are faced with the problem of understanding the true definition of a pop-up store and being able to know where it stands within the marketing or distribution channels. 


\section{Methodology}

Due to the nature of the situation at hand, an exploratory study seemed most relevant. Employing semi-structured interviews (Alexander, et al. 2018) and field observations (Rudkowski, et al. 2020), valuable data was collected from different brand managers and entrepreneurs who have actively engaged in pop-up stores in Lebanon. Brands have been actively installing pop-up stores in the city of Beirut; however, the market had not been explored by academics yet. This study aims at discovering and exploring (Frisch, 1999) common practices of Lebanese brand managers with regards to their understanding and usage of pop-up stores.

\section{Semi-structured interviews}

Semi-structured interviews are best suited for an in-depth understanding of a given subject (Lunardo, et al., 2012 and Sabiote \& Ballester, 2011). They are credible sources of data collection and are used in exploratory studies (Mencarelli, 2008 and Fosse-Gomez \& Ōzçaglar-Toulouse, 2009), empirical studies (Mayrhofer \& Roederer, 2009), or interpretive studies (Lemoine, 2010). A relatively heterogeneous sample was interviewed (Lunardo, et al., 2012) during December 2015 and January 2016 in Beirut, Lebanon: a diversity of respondent profiles, ranging from high-end speciality stores to low-end ranges, across retail sectors. A total of 15 brand managers (30\% managing emerging brands and $70 \%$ managing mature brands), having directly worked on a pop-up store project or having supervised a pop-up store project, were interviewed. The conversation was led by a revised semi-structured interview guide. After having taken permission to record the interview, the average time of exchange on the topic was 28 minutes. Data collection stopped when gathered information became repetitive; at this point, a semantic saturation level was achieved (Frippiat \& Marquis, 2010).

\section{In situ-Observations.}

Semi-structured interviews made it possible to grasp the nature of the ephemeral stores, their interests and the reasons why managers are adopting them. Observation guides made it possible to approach, with further precision, the manifestation of brands through pop-up stores and their relationship with customers. These complementary methods (Poncin \& Garnier, 2012) were associated to lead to a complete reading of the subject at hand.

In-situ observation helped to describe a pop-up store and its specificities (Evrard, et al., 2009). Our objective was to link together the threads related to the concept, the theme, the selection of products, the brand representatives, the crowd, the place, the location and so on (Bonnin, 2003 and Ghosh \& Craig, 1983). After having visited the pop-up stores in Beirut, between the period of December 2015 and January 2016, we have filled in the observation grids (Evrard, et al., 2009) with notes that were collected during the visits (Pomodoro, 2013). All photos taken in each of the stores were also saved to be considered in the analysis.

Semi-structured interviews and in-situ observation enabled us to triangulate collected data (PicotCoupey, 2014) as they displayed different and varied points of view. All collected data were digitally recorded and transcribed; double translations, French/English or Arabic/English, were performed when necessary. All pictures were digitally saved and organized under the relevant observed store's name, date and location.

We refer to established brands and establishing brands in the remainder of the paper: The former represents brands that have been on the market for a long time and have considerable recognition, and the latter refers to start-ups or brands in the process of development.

\section{Pop-up store classifications and characteristics}

What defines a pop-up store is its ability to reflect a specific season, respond to timing and adapt to a given location. Concerning the (establishing or established) brand's identity and position on the market, a clear strategic direction separates the pop-up store's course from being independently used as a distribution channel, a communications channel or both, and can be inscribed amongst multiple brand distribution channels.

The strategy is then operationalized with a set of objectives, such as testing, experimenting, triggering actions or advancing an experience. The pop-up store's chosen format reflects the brand's identity and the strategic discourse, and will, in turn, inspire the environment, atmosphere, and theme. Displaying 
products or services, or simply proposing a space with messages answers to the initial brand pop-up store's raison d'être. The pop-up store's descriptive and characterizing aspects refer to its limitation in time, the location it adopts and the seasonality during which it appears.

\section{Pop-up store characterising features}

Even though there are many common practices between different brands at different industry levels and with different positioning, our study highlighted a typology that puts forward two brand classes: establishing brands and established. The first type, establishing brands, looks at those brands in their early life cycle and who have minimal resources or no resources. They tend to operate haphazardly, opening space for trial and error. The latter is reserved to mature brands who can operationalize their resources with greater flexibility. Established brands are focused on their approach; they inscribe it in a long-term plan that considers the pop-up as part of other channels (whether online or offline) that it owns.

Figure 1-Defining pop-up stores

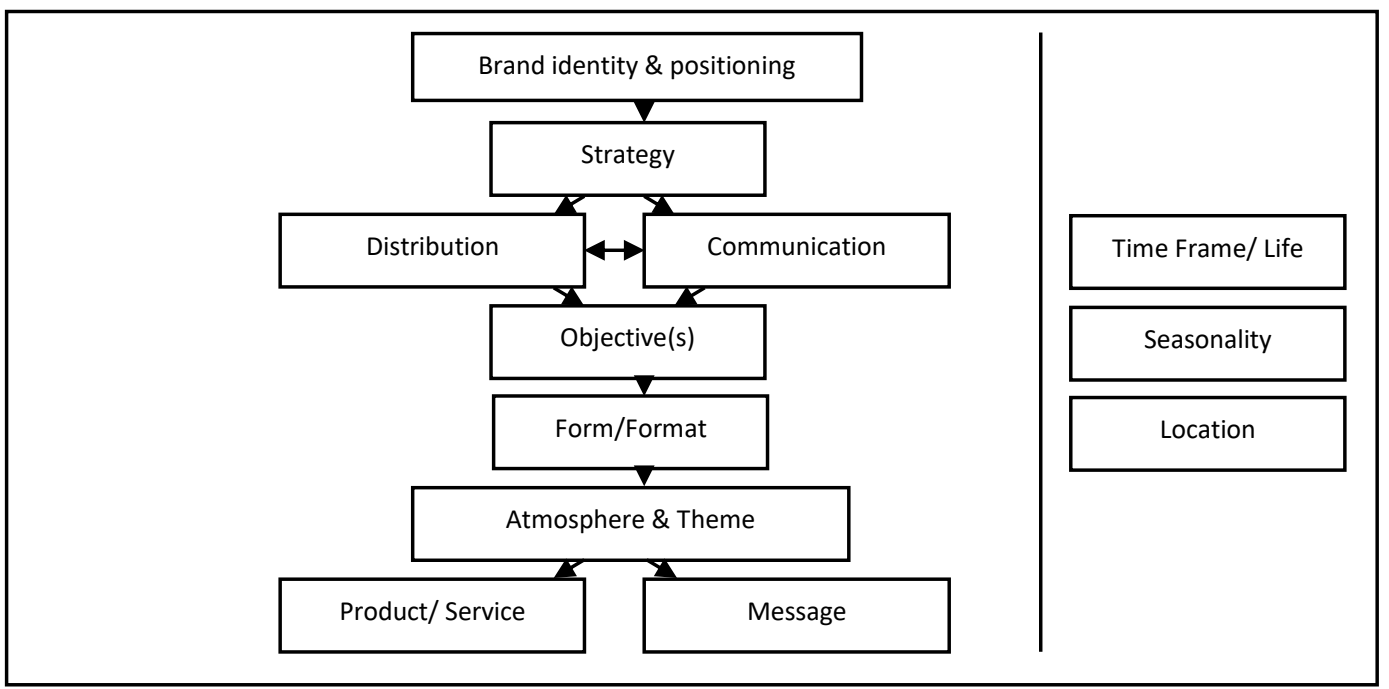

Common to both types of brands is customer-centricity. Customer behaviours guide brands, along their life cycle, in all aspects related to strategic decisions (Bauer \& Auer-Srnka, 2012). A clear strategy directs brands into "what" actions are needed to be taken followed by "how" they will be applied. At both ends of the spectrum, setting up a pop-up store considers how the store format's atmosphere is going to be designed and what will be proposed in the atmosphere (Alexander, et al.2018). Knowing that it has to respect a given time, seasonality (Zola, 1999 and Bishop \& Williams, 2012) and choose a relevant location (Moore \& Fairhurst, 2003).

At an early stage of the brand's development, distribution and communications activities aim to gather the highest number of consumers to create brand awareness (Surchi, 2011, Picot-Coupey, 2014 and Russo Spena, et al., 2012). They also announce its presence on the market and gain eventual recognition and positive associations. Mature brands focus on a specific purpose when developing a pop-up store. They operationalize all brand elements at all touchpoint levels to speak the same language. This results in greater efficiency and effectiveness.

Information gathered from the exploratory study showed that an establishing brand's purpose is to engage in pop-up stores to "create a momentum", as they need it to connect with consumers and try to engage in a relationship with them. Pop-up stores help establishing brands explore distribution or communications channels; as at early stages, they seek maximum visibility. They also help establishing brands in exploring the physical space and evaluating it before making decisions related to the possibility of moving to a permanent physical location. Mobility and access to new markets bring to light a brand to customers, competitors or potential buyers and investors. Pop-up stores allow a novice brand to take the 
extra mile and seek expansion opportunities outside of its comfort zone, whether locally or across borders, in different formats and so on.

A pop-up store shrinks the time between information sharing, customer response, and merchandise movement. We are keen on differences between brand business models, seniority on the market and the maturity level it has reached. Nevertheless, what is apparent and common amongst established brands is the clarity in terms of vision when it comes to working with pop-up stores. These brands go to where customers are, they search for a well-thought location considering customer dwell and accessibility. They conceive a pop-up store to attract, capture and turn heads; it could be a communications medium by its rights or can be a channel through which an offering is proposed to customers. When a brand's strategy is inscribed in multi-channel or omnichannel retailing, the pop-up store's atmosphere becomes a crucial touchpoint connecting customers to the brands' social channels, online stores, physical stores and so on. The availability of funds and willingness to invest in a pop-up store affects its form, atmosphere and the extent to which a customer experience is designed.

This research classifies pop-up stores as establishing brands and established brands, whereby the first-class looks at brands that are at a very young phase of the life cycle and the second has already reached maturity. A brand's resources are the main dividers to developing a pop-up store: capabilities, expertise and capital. The purpose and function refer to objectives a pop-up store aims to meet and the relevant ways it will employ to do so.

\begin{tabular}{|c|c|c|c|c|}
\hline & Driver & Purpose (What) & Function (How) & Approach \\
\hline \multirow{4}{*}{$\begin{array}{l}\text { New/Developing } \\
\text { brands }\end{array}$} & \multirow{4}{*}{ "lack" of resources } & Create a momentum & $\begin{array}{l}\text { Advance an experience \& } \\
\text { socialise }\end{array}$ & \multirow[t]{4}{*}{ Short-term } \\
\hline & & $\begin{array}{l}\text { Explore a new } \\
\text { channel }\end{array}$ & $\begin{array}{l}\text { Create excitement and } \\
\text { desirability }\end{array}$ & \\
\hline & & $\begin{array}{l}\text { Expand } \\
\text { opportunities }\end{array}$ & Intrigue & \\
\hline & & & Test/Experiment/Learn & \\
\hline \multirow{5}{*}{$\begin{array}{l}\text { Mature/ } \\
\text { Established brands }\end{array}$} & \multirow{5}{*}{$\begin{array}{l}\text { "operationalization" } \\
\text { of resources }\end{array}$} & Location availability & $\begin{array}{l}\text { Advance an experience \& } \\
\text { socialize }\end{array}$ & \multirow[t]{5}{*}{ Long-term } \\
\hline & & Attention-grabbing & Trigger (specific) action & \\
\hline & & Communicate & $\begin{array}{l}\text { Create a buzz/ Trigger } \\
\text { word of mouth }\end{array}$ & \\
\hline & & Sell/ Move stock & Create a hype & \\
\hline & & & Test/Experiment/Learn & \\
\hline
\end{tabular}

Table 1- Categorization of Pop-up Stores

\section{Positioning pop-up stores}

The malleability that a pop-up store presents to brands makes it less of a conformed retail format. Depending on the brand's nature, identity, and strategic decisions, it chooses to position the pop-up store under its communications channel, distributions channel or simultaneously under both channels. Operating as a pop-up or operating with a pop-up? By "nature of the brand" we mean whether the brand is an online or offline operation or operates with various distributions channels. Pop-up stores are implanted to serve the brand's strategy to either exist as a sole physical format, as a supporting physical format or as a complement to its digital presence.

Literature explained the origins and nature of pop-up stores and the triggers that led to their development. It presents cases describing how pop-up stores support and complement digital brands, how pop-up stores are used to expand into other markets, how pop-up stores are exploited to promote 
and distribute, simultaneously, seasonal lines in seasonal locations or meet up potential buyers and customers during yearly calendar events (Langlois, 2002; Vandaele, 1986 and Niehm, et al., 2007).

Pop-up stores allow shrinking the time for customers to move between several brand distributions channels and thus consolidate several touchpoints (Jain \& Bagdare, 2009) in one place and a defined time frame. The brand can disseminate a message through different communications channels (online and offline), repeat the message on the pop-up store's site, propose products and services along with team support onsite, and allow customers to instantly have feedback and share it with others (onsite, online or by propagating word-of-mouth).

The pop-up store's atmosphere is equipped with all facilitating information (website address, social site addresses, QR codes, hashtags, weblinks, physical store addresses, contact numbers or email addresses ). In cases when the pop-up is purely intended to communicate a message without displaying any merchandise, it will still use different tools to move the customer between its various channels, such as its store, website, social sites. A pop-up store is a unique tool in its rights. It can be manipulated according to the brand's needs, conditional to following a defined strategy and set to achieve specific objectives.

\begin{tabular}{|c|c|c|}
\hline Brand categorization & Purpose and function & Typology \\
\hline & \multirow{5}{*}{$\begin{array}{l}\text { Concept/Identity } \\
\text { Pop-up's positioning } \\
\text { Strategy } \\
\text { Objectives }\end{array}$} & Pop-up as Distribution Channel \\
\hline New/Developing brands & & Pop-up as Communication Channel \\
\hline \multirow{3}{*}{ Mature/ Established brands } & & Pop-up as Distribution \& \\
\hline & & Communication Channel \\
\hline & & Distribution Channel(s) \\
\hline
\end{tabular}

Table 2-Typology of Pop-up Stores

A brand is encouraged to "dress up differently" when popping up in different locations. Respecting the brand's idea is key to presenting the pop-up store's format and design; even if the brand represents itself in different looks, they should all project a unique identity: the ephemeral store must be coherent and congruent with its identity; it must speak the same language across all brand touchpoints, including popup stores. The choice of elements composing the pop-up store's atmosphere is of major importance as it is the point of direct contact between the brand and the consumer. Product choice, light, music, installations, decorations; all "saying the same thing".

Conceiving, communicating and launching the ephemeral store at the right time and in the right place attract the (desirable) consumer profile and entices him to visit. It is at the moment of the consumer's contact with the atmosphere that he will interact with the brand and experience feelings of joy and excitement. Those who are most interested in the offer (in case it is presented) will buy or spend more time examining the space, spend time learning, or just spend a pleasant interacting with the space or with others. An important duality becomes more apparent; the brand wants to create an appealing environment with which the customer can interact, and the customer desires to interact with the brand's environment and derives a positive outcome. Noticeably, the social dimension appears to be of major importance for both the brand and the customer.

The pop-up store itself becomes an entity that the brand deliberately manipulates and shapes to distribute and/or communicate the brand's products, services or information, to achieve specific objectives. It acts as a vivid, dynamic, bubbly format that engages, surprises and delights customers and that brand managers consider as a "happy event."

\section{Discussion of the findings}

With a clear purpose in mind, an established or establishing brand uses the pop-up store to explore or add up to its existing distribution channels or to create a brand happening at a given moment in time. The pop-up store becomes itself the medium, a source of stimulation (Bonnin, 2006) and a brand representation conceptualizing its identity and personifying its character. It provides the space and means to interact and get closer to customers, conveys a message, and when needed, allows transactions and exchange to take place. In any of the reasons leading to the adoption of a pop-up store, they have to 
funnel down to the finality of meeting a brand's strategic objective (Pontier, 1988) and advancing a customer experience (Sohier \& Bree, 2014; Roederer, 2012; Babin, et al., 1994 and Filser, 2008).

"Experiences" are the result of an individual's interaction with a given object in a given situation (Jain \& Bagdare, 2009); they requisite consumer interaction and active participation (Pine \& Gilmore, 1999 and Carù \& Cova, 2003) in a given context (Srinivasan \& Srivastava, 2010). When there are fewer investments to creating experiential environments (Russo Spena, et al., 2012 and Kim, et al., 2010), minimal interactions will be notably experienced by customers (Antéblian, et al., 2013). The experience's valance in a pop-up store varies in function of the experiential context and its ability to provide grounds of contact between an individual and the brand.

Understanding the brand experience seems to differ along the opposite sides of the spectrum. This draws attention to establishing brands, having fewer investment capabilities in hand, and who are less able to create experiential outlets allowing customers to develop experience, as opposed to established brands. The pop-up store becomes one of the brand's touchpoints (Surchi, 2011) that guarantees, due to its characteristics, a direct relationship and interaction between the brand and customer to finally lead to memorabilia (Pine \& Gilmore, 1998). Even though it is a common discourse to say that pop-up stores deliver experiences, they would be less able and capable to do so without considerable investments for conceptualization, establishment, and operationalization of the pop-ups format.

It seems optimistic that a newly established brand, with minimal resources, creates an experiential environment that can induce a customer experience (Taube \& Warnaby, 2017). For newly established brands, offering a brand experience through a pop-up store looks at proposing to customers something different and new (Picot-Coupey, 2014). However, it seems that these brands are not offering something that customers perceive as "new"; rather, they are portraying something "new"; something that the brand has not done beforehand and that goes beyond utilitarian consumption (Hirschman \& Holbrook, 1982). If customers don't see the value in the brand's offering, then they will be less inclined to take positive action towards the newly established brand's pop-up.

Having a unique feature, flexibility, and malleability, the pop-up store's attribution under distributions or communications relates to the initial purpose that a brand has thought of to meet a specific objective: pop-up stores become a means to an end. Established brands value the fact that a popup store elicits customer emotional reactions. This is linked to the understanding that the store's conception, its ability to appropriate customers (Bonnin, 2002) and the offering's presentation should elicit emotional reactions. Emotional reactions should lead to positive behavioural reactions, such as purchase response and an increase of the time spent in the pop-up store.

Creating demand through a pop-up store falls under the logic of coordinating effects amongst several brand distribution channels and paving the way for customers' active participation through and within (Cardoso, et al., 2013 and Hart, et al., 2000). The pop-up store could be considered as a tool to communicate when a brand operates with different distribution channels or could be used as a means to sell if the (established) brand is hoping to promote a specific offering (Lowe, et al., 2018).

Customers might have different experiences throughout the pop-up store's life. The large majority of pop-up stores communicate before the happening, during and after the pop-up store's implantation. It is not a rule of thumb that a customer's experience is consistently maintained across all stages of the pop-up store; it can alter between positive or negative valence along the way. Established and establishing brand managers refer to the brand's positioning to set up a clear pop-up strategy. They look at all aspects and stages of the pop-up store's development and realization to meet all set objectives.

\section{Limitations and future research avenues}

This study, being carried out on the Lebanese market may reflect local specificities. It would be interesting to collect data from European, American and Asian markets to identify similarities or differences related to pop-up stores. Given the exploratory nature of our research, conclusions drawn deserve to be put into perspective. Indeed, our study has limited external validity due to the size and composition of our sample. The study could also be repeated in Lebanon, to examine the phenomenon across several geographical areas and take across borders of other Middle Eastern countries; this to confirm findings related to the pop-up store typologies and to be able to compare them to typologies that could be relative to other markets. 
In the context of our study, the number of interviews has been stopped as soon as we reached a semantic saturation threshold. In cases when there might be a possibility to explore points of view of other pop-up store brand managers operating in different geographical areas, we could hope to find other discourses enriching information about pop-up retail. Previous studies have put forward pop-up store categorizations in a fashion-related context. Four conceptual and theoretical categories were identified (Pomodoro, 2013): "a concept brand store, a community store, a test store and a sustainable temporary store". After having defined and classified pop-up stores, we put forward a typology for pop-ups: depending on the brand's class and under the guidance of a clear strategy and defined objectives, four types of pop-up stores can be identified: The pop-up store as Distribution Channel, The pop-up store as Communication Channel, The pop-up store as Distribution Channel and Communication Channel and finally, The pop-up store as a complement to the distribution channel.

The qualitative data collection's synthesis highlights pop-up store characterizing features on the Lebanese market: A pop-up store is a creative platform through which the brand put forward a retail format designed to innovatively serve a previously established purpose. It is the pop-up store's idea (or concept) that is central to its design. Future studies related to the understanding of pop-up stores suggest collecting qualitative data for an extended period. This allows gathering a greater and varied amount of information to examine and study. Pop-up stores are highly concentrated in the area of Beirut, Lebanon; no other pop-up stores have been reported in other Lebanese cities during the time of the study. Therefore, other representations in other major cities might have led to observing different store formats and varied interpretations.

\section{Conclusion}

Despite the adoption of pop-up stores by brands and their integration in brand retail strategies, there is still ambiguity around the definition of pop-up retail and a pop-up store. This research aimed to put forward a definition that clarifies the nature and utilities of pop-up stores.

Am establishing or established brand, with a clear identity and positioning, draws clear objectives that it aims to meet from its communications or distributions strategy. The choice of the pop-up store's format and shape reflect the brand's identity and will directly influence the pop-up store's atmospheric conception, the choice of products and the communicated message. Fundamental to any pop-up store is its implantation at the right place, time and with the perfect timing.

The eccentricity of pop-up stores makes them more appealing to customers and entices bands to reinvent the retail environment and experience. This research highlights the importance of conceiving pop-up stores with attention to brand identity and their integration with brand distribution and communications practices. It also emphasizes the importance of planning the pop-up store in such a way that makes it relevant and appealing, here and now. Retailers can highly benefit from pop-up stores as they help them meet commercial or non-commercial objectives. However, this does not mean that pop-up stores will be a winning solution for any brand and at any time. Careful planning of pop-up store applications and an understanding of efforts that have to be made at all brand levels are not to be overlooked.

\section{References}

Addady, m., 2016. Here's how many pop-ups stores amazon plans to open. [Online] Available at: http:// fortune.com/2016/09/09/amazon-pop-up-stores/ [Accessed 17 January 2017].

Alexander, b., Nobbs, K., Varley, r. 2018. The growing permanence of pop-up outlets within the international location strategies of fashion retailers. International Journal of Retail \& Distribution Management, 46 (5), pp.487-506

Antéblian, b., filser, m. \& roederer, c., 2013. The consumer experience in retailing. A literature review (L'experience du consommateur dans le commerce de detail. Une revue de literature). Recherche et applications en marketing, 28(3), pp. 84-114.

Babin, B. J., darden, w. R. \& griffin, M., 1994. Work and/or fun: measuring hedonic and utilitarian shopping value. Journal of consumer research, mars, 20(4), pp. 644-656.

Badot, o., poulain, m. \& camus, s., 2013.

Spirituality in the shopping experience. Theoretical framework and empirical exploration 
The consumer experience in retailing. A review of the literature (La spiritualité dans l'expérience de magasinage. Cadre théorique et exploration empirique). Rimhe : revue interdisciplinaire management, homme \& entreprise, 8(4), pp. 40-56.

Bauer, m. \& auer-srnka, k. J., 2012. The life cycle concept in marketing research. Journal of historical research in marketing, 4(1), pp. 68-96.

Bishop, p. \& williams, 1., 2012. The temporary city. London: routlege.

Bonnin, g., 2002. Store and shopping experience: the role of ownership (Magasin et expérience de magasinage : le rôle de l'appropriation). Décisions marketing, oct.-déc., issue 28, pp. 65-75.

Bonnin, g., 2003. Consumer mobility in stores: an exploratory study of the influence of spatial planning on the appropriation strategies of mass retail spaces (La mobilité du consommateur en magasin : une étude exploratoire de l'influence de l'aménagement spatial sur les stratégies d'appropriation des espaces de grande distribution). Recherche et applications en marketing (marketing spécial), 18(3), pp. 7-29.

Bonnin, g., 2006. Physical environment and service experience: an appropriation- based model. Journal of services research, july, 6(special issue), pp. 46-62.

Boustani, g., 2019. Ephemeral retailing. Pop-up stores in a postmodern consumption era. London: Routledge, p. 126

Boustani, g., 2021. Pop-up store adoption by brands. Journal of textile science \& Fashion technology, 7(5), pp.1-5

Cambridge dictionnary, n.d. Cambridge business english dictionary. [online] available at:

https://dictionary.cambridge.org/dictionary/english/pop-up-store [accessed 31 January 2018].

Carapiet, 1., 2009. Pop-up shops quite the fashion. [online] available at: www.lexisnexis.com (the Australian financial review). [accessed 30 april 2009].

Cardoso, f., pinot, f. \& badot, o., 2013. Myths and rites of postmodern consumption: the shopping cidade jardim case. Chicago, s.n., pp. 204-205.

Carù, a., 2003. An empirical approach to immersion in the consumer experience: appropriation operations (Approche empirique de l'immersion dans l'expérience de consommation : les opérations d'appropriation). Recherche et applications en marketing, 18(2), pp. 47-65.

Daily star, 2015. www.dailystar.com/life/lubnan. [online] available at:

http://www.dailystar.com.lb/life/lubnan/2015/aug-04/309536-souk-el-akel-a-market-with-asoul. ashx. [accessed 14 mars 2016].

Dean, w., 2012. Independent.co.uk. [online] available at: http://www.independent.co.uk/news/uk/thisbritain/the-pop-up-paradigm-they-may-not-lastfor- long-but-temporary-shops-are-here-to-stay6294576.html. [accessed 14 mars 2016].

Diegel, a., 2014. Spreecommerce. [online] available at: https://spreecommerce.com/blog/ecommercepopup-shops. [accessed 2 february 2018].

Economist, 2009. Gone tomorrow. [online] available at:

http:// www.economist.com/business/finance/displaystory.cf,?storyid=14101585\&fsrc=rss. [accessed 20 august 2009].

Evrard, y., pras, b. \& roux, e., 2009. Market. 4e édition ed. Paris: dunod.

Filser, m., 2008. The consumer experience: concepts, models and managerial issues (L'expérience de consommation : concepts, modèles et enjeux managériaux). Recherche et applications en marketing, septembre , 23(3), pp. 1-4.

Filser, m., 2011. Re-enchanting the shopping experience: case studies from france. European retail digest, june, issue 30, pp. 39-40.

Fortini, a., 2004. The anti-concept concept store. [online] available at: www.nytimes.com [accessed 30 april 2009].

Fosse-gomez, m. H. \& ōzçaglar-toulouse, n., 2009. Increasing purchasing power through self-reduction. The Robin Hood of the supermarkets (Augmenter le pouvoir d'achat par l'autoréduction. Les robins des bois des supermarchés). Décisions marketing, octobredécembre, issue 56, pp. 63-73.

Frippiat, d. \& marquis, n., 2010. Internet surveys in social sciences: a state of the art (Les enquetes par internet en sciences sociales : un état des lieux). Population-f, 65(2), pp. 309-338. 
Frisch, f., 1999. Qualitative studies. Editions of organization (Les études qualitatives. Éditions d'organization) ed. S.1.:eyerolls .

Gagliordi, n., 2012. Retail customer experience. [online] available at:

http://www.retailcustomerexperience.com/articles/pop-up-retail-grows-up/. [accessed 31 January 2018].

Ghosh, a. \& craig, c. S., 1983. Formulating retail location strategy in a changing environment. Journal of marketing, summer.pp. 56-68.

Girish, d., 2016. Quora. [online] available at: https://www.quora.com/what-are-the-pros-and-cons-of-apop-up-store. [accessed 30 January 2018].

Go vacant, 1999. Go vacant. [online] available at: http:/ / www.govacant.com/. [accessed 30 January 2018].

Hallisy, b., 2006. Taking it to the streets: steps to an effective- and ethical- guerilla marketing campaign. Public relations tactics, 13(3), p. 13.

Hart, c., doherty, n. \& ellis-chadwick, f., 2000. Retail adoption of the internet: implications for retail marketing. Europen journal of marketing, 34(8), pp. 954-974.

Hirschman, e. C. \& holbrook, m. B., 1982. Hedonic consumption: emerging concepts, methods, and propositions. Journal of marketing, summer, 46(3), pp. 92-101.

Horne, m., 2014. Temporary use of pop-up environment's potential for repurposing neglected buildings and spaces. Georgia state university, 510 .

Hutchison, j., 2009. In praise of the pop-up: retail's new future. [online] available at: http://luxurysociety.com/en/articles/2009/12/in-praise-of-the-pop-up-retails-new-future/ [accessed 31 January 2018].

Influencia, 2015. The consumer in need of popup stores (Le consommateur en manque de popup stores). [online] available at:

http://www.influencia.net/fr/actualites/tendance,etudes,consommateur-manque-pop-upstores, 5051.html. [accessed 30 January 2018].

Jain, r. \& bagdare, s., 2009. Determinants of customer experience in new format retail stores. Journal of marketing \& communication, september-december, 5(2), pp. 34-44.

Kerr, a., 2007. Disruptive retailing. [online] available at: www.boutiqueindustry.blogspot.com [accessed 12 May 2009].

Kim, h., fiore, a. M., niehm, 1. S. \& jeong, m., 2010. Psychographic characteristics affecting behavioral intentions towards pop-up retail. International journal of retail \& distribution management, 38(2), pp. 133-154.

Kim, e., 2016. Amazon is doubling down on retail stores with plans to have up to 100 pop-up stores in us shopping malls. [online] available at: http://www.businessinsider.com/amazonbig-expansion-retailpop-up-stores-2016-9 [accessed 30 January 2018].

Klépierre \& qualiquanti , 2015 . Pop-up stores: the conquest of a territory of expression for brands (Pop-up stores: la conquête d'un territoire d'expression pour les marques), s.l.: s.n.

Koch, d., 2006. Pop-up shops. [online] available at: www.retailtrafficmag.com. [accessed 12 May 2009].

Langlois, s., 2002. New directions in consumer sociology (Nouvelles orientations en sociologie de la consummation). L'année sociologique, 1(52), pp. 83-103.

Lemoine, j.-f., 2010. Research in e-marketing: state of the art and perspectives (Les recherches en emarketing : état des lieux et perspectives). Revue management et avenir, fevrier, issue 32, pp. 109-112.

Lipovetsky, g. \& serroy, j., 2016. The aesthetics of the world. Living in the age of artist capitalism (L'esthétisation du monde. Vivre à l'âge du capitalisme artiste). Editions gallimard ed. Paris: gallimard.

Losif, r., 2015. Viuz. [online] available at: https://viuz.com/2015/10/29/le-phenomene-despop- upstores-parti-pour-durer/?trk=pulse-det-art_view_ext [accessed 31 January 2018].

Lowe, j., maggioni, i. \& sands, s., 2018. Critical success factors of temporary retail activations. A multiactor perspective. Journal of retailing and consumer services, volume 40, pp. 74-81.

Lunardo, r., saintives, c. \& roux, d., 2012. An exploratory study of consumer control inferences in the face of store atmosphere (Une étude exploratoire des inférences de contrôle du consommateur face à l'atmosphère du point de vente). Management et avenir, issue 55, pp. 55-78. 
Maille, v. \& fleck, n., 2011. Consumer-perceived congruence: towards a clarification of the concept, its formation and measurement (Congruence perçue par le consommateur : vers une clarification du concept, de sa formation et de sa mesure). Recherche et applications en marketing, 26(2), pp. 78-111.

Mandelbaum, r., 2013. The new york times magasine. [online] available at:

http://www.nytimes.com/packages/html/magazine/2013/innovationsissue/\#/ ?part=popupstore [accessed 30 January 2018].

Marciniak, r. \& budnarowska, c., 2009. Marketing approaches to pop-up stores: exploration of social networking. Surrey, s.n.

Mayrhofer, u. \& roederer, c., 2009. Sell where they shop levi strauss signature ${ }^{\circledR}$ : a new retail brand (Sell where they shop levi strauss signature ${ }^{\circledR}$ : une nouvelle marque pour la grande distribution). Recherches et publications en management a.s.b.l, 26(5), pp. 15-25.

Mencarelli, r., 2008. (Place-object interaction as a conceptualization of lived experience: testing an integrative model ) L'interaction lieu-objet comme conceptualisation de l'expérience vécue : test d'un modèle intégrateur. Recherche et applications en marketing, septembre, 23 (3), pp. 51-69.

Moore, m. \& fairhurst, a., 2003. Marketing capabilities and firm performance in fashion retailing. Journal of fashion marketing and management, 7(4), pp. 386-397.

Newton, a., 2017. Retail next. [online] available at: https://retailnext.net/en/blog/6-reasonswhy- pop-upstores-are-excelling/ [accessed 30 January 2018].

Niehm, 1. S., ann marie, f., jeong, m. \& kim, h.-j., 2007. Pop-up retail's acceptability as an innovative business strategy and enhancer of the consumer shopping experience. Journal of shopping center research, 13(7), pp. 1-30.

Picot-coupey, k., 2014. The pop-up store as a foreign operation mode (fom) for retailers. International journal of retail \& distribution management, 42(7), pp. 643-670.

Picot-coupey, k., 2012. Pop-up stores and the international development of retail networks. Venice, international marketing trends conference.

Pine, j. \& gilmore, j., 1999. The experience economy. S.l.: hbs press.

Pine, j. B. \& gilmore, j. H., 1998. Welcome to the experience economy. Harvard business review, julyaugust.pp. 98-105.

Pomodoro, s., 2013. Temporary retail in fashion system: an explorative study. Journal of fashion marketing and management, 17(3), pp. 341-352.

Poncin, i. \& garnier, m., 2012. The experience on a $3 \mathrm{~d}$ sales site. The real, the fake and the virtual: at the crossroads (L'expérience sur un site de vente $3 \mathrm{~d}$. Le vrai, le faux et le virtuel : à la croisée des chemins). Revue management et avenir, 2(32), pp. 173-191.

Pontier, s., 1988. Image du point de vente : pour une prise en compte de l'image interne. Recherche et applications en marketing, 3(3), pp. 3-19.

Roederer, c., 2012. Contribution to the conceptualization of the consumer experience: emergence of the dimensions of the experience through life stories (Contribution à la conceptualisation de l'expérience de consommation : émergence des dimensions de l'expérience au travers de récits de vie). Recherche et applications en marketing, 27(3), pp. 81-96.

Russo spena, t., carida, a., colurcio, m. \& melia, m., 2012. Store experience and co-creation: the case of temporary shop. International journal of retail \& distribution management, 40 (121-40).

Rudkowski, Janice \& Heney, Chelsea \& Yu, Hong \& Sedlezky, Sean \& Gunn, Frances, 2020. "Here Today, Gone Tomorrow? Mapping and modeling the pop-up retail customer journey," Journal of Retailing and Consumer Services, Elsevier, vol. 54(C).

Ryan, j., 2008. Retail week. [online] available at: http://www.retailweek. com/stores/retailings-bit-ofrough/5007452.article [accessed 1 fevrier 2018].

Sabiote, e. \& ballester, m., 2011. Experience brands: making a difference (Marcas de experiencia: marcando la diferencia). Estudios generales, octubre-diciembre.27(121).

Sherman, 1., 2008. Forbes. [online] available at: http://www.forbes.com/2008/02/01/popupstores- retaildesigners-forbeslife-cx_ls_0201popup.html [accessed 1 fevrier 2018].

Shopify, n.d. Shopify.com/guides/howtopicktheperfectlocation. [online] available at: 
www.shopify.com/guides/ultimate-guide-to-pop-up-shops/how-to-pick-the-perfect-location [accessed 09 mars 2016].

Sohier, a. \& bree, j., 2014. The perception of rock, an essential dimension of satisfaction among rock festival spectators (La perception du rock, une dimension essentielle de la satisfaction chez les spectateurs des festivals rock). Décisions marketing, juillet-septembre, volume 75, pp. 95- 115.

Srinivasan, s. \& srivastava, r., 2010. Creating the futuristic retail experience through experiential marketing: is it possible? An exploratory study. Journal of retail \& leisure property, 9(no.3), p. 193199.

Stephens, d., 2012. [online] available at: http://www.retailprophet.com/blog/storeexperience/ thefuture-is-temporary/ [accessed 07 mars 2016].

Storefront, n.d. Storefront. [online] available at:

https:// www.thestorefront.com/?gclid=cj0kcqiazmdtbrddarisabx4awws35q3jp3et-6oyuar1wztah2x3mrv11ryqhae_bpig6ezemssd8aatewealw_wcb [accessed 2018 January 2018].

Surchi, m., 2011. The temporary store: a new marketing tool for fashion brands. Journal of fashion marketing and management, 15(2), pp. 257- 270.

Taube, j., \& Warnaby, g. 2017. How brand interaction in pop-up shops influences consumers' perceptions of luxury fashion retailers. Journal of fashion marketing and management. 21 (3), pp. 1361-2026.

Tomlinson, m., 2014. [online] available at: www.business.ee.co.uk

Vandaele, m., 1986. Le cycle de vie du produit : concepts, modèles et évolutions. Recherche et applications en marketing, 1(2), pp. 75-87.

Zola, e., 1999. The Ladies' Paradise (Au bonheur des dames). Paris: flammarion. 